\title{
Optimization of Extraction Conditions of Some Phenolic Compounds from White Horehound (Marrubium vulgare L.) Leaves
}

\author{
Karim Bouterfas ${ }^{*}$, Zoheir Mehdadi' ${ }^{1}$, Djamel Benmansour ${ }^{2}$, Meghit Boumedien Khaled ${ }^{3}$, \\ Mohamed Bouterfas ${ }^{4}$, Ali Latreche ${ }^{1}$ \\ ${ }^{1}$ Laboratory of Vegetal Biodiversity: Conservation and Valorization, Faculty of Life and Natural Sciences, \\ Djillali Liabes University, Sidi Bel-Abbes, Algeria \\ ${ }^{2}$ Laboratory of Statistics and Random Model, Faculty of Natural and Universe Sciences, \\ Abou-Bekr Belkaid University, Tlemcen, Algeria \\ ${ }^{3}$ Department of Biology, Faculty of Natural and Life Sciences, Université Djillali Liabes, \\ Sidi Bel Abbes, Algeria \\ ${ }^{4}$ Laboratory of Microscopy, Microanalysis of the Matter and Molecular Spectroscopy, Faculty of Exact Sciences, \\ Djillali Liabes University, Sidi Bel-Abbes, Algeria \\ Email: ${ }^{*}$ bouterfas karim@yahoo.fr
}

Received 12 October 2014; revised 28 November 2014; accepted 13 December 2014

Copyright (C) 2014 by authors and Scientific Research Publishing Inc.

This work is licensed under the Creative Commons Attribution International License (CC BY). http://creativecommons.org/licenses/by/4.0/

c) (i) Open Access

\section{Abstract}

This research was aimed to optimize the extraction conditions of three phenolic compounds: total phenolics, flavonoids and condensed tannins, from White Horehound's leaves (Marrubium vulgare L.). Distilled water and different organic solvents such as: methanol, ethanol and acetone, were used, with various concentrations $(20 \%-80 \%, v / v)$, temperatures $\left(20^{\circ} \mathrm{C}-60^{\circ} \mathrm{C}\right)$ and extraction times (30 - $450 \mathrm{~min})$. Results showed that the maximum total phenolics amounts $(293.34 \pm 14.60$ mg gallic acid equivalent/g dry weigh), were obtained with $60 \%$ aqueous methanol at $25^{\circ} \mathrm{C}$ for 180 min; total flavonoids (79.52 $\pm 0.55 \mathrm{mg}$ catechin equivalent/g dry weigh) with $80 \%$ aqueous methanol at $20^{\circ} \mathrm{C}$ for $450 \mathrm{~min}$, and condensed tannins $(28.15 \pm 0.80 \mathrm{mg}$ catechin equivalent/g dry weigh) with $60 \%$ aqueous acetone at $50^{\circ} \mathrm{C}$ and for $180 \mathrm{~min}$. ANOVA test showed the significant effect $\left.{ }^{* * *} P<0.001\right)$ of the extraction conditions tested on phenolic compounds. The Principal Component Analysis (PCA) exhibited the positive effect of low temperatures on total phenolics and flavonoids extraction, and the effect of high temperatures on the condensed tannins extraction. The Response Surface Methodology (RSM) provided predicted values of extraction conditions and maximum polyphenols amounts similar to those obtained experimentally.

${ }^{*}$ Corresponding author.

How to cite this paper: Bouterfas, K., Mehdadi, Z., Benmansour, D., Khaled, M.B., Bouterfas, M. and Latreche, A. (2014) Optimization of Extraction Conditions of Some Phenolic Compounds from White Horehound (Marrubium vulgare L.) Leaves. International Journal of Organic Chemistry, 4, 292-308. http://dx.doi.org/10.4236/ijoc.2014.45032 
Keywords

Marrubium vulgare, Phenolic Compounds, Optimization, Extraction Conditions

\section{Introduction}

Polyphenols constitute one of the most common and widespread groups of substances in flowering plants, occurring in all vegetative organs, as well as in flowers and fruits. These molecules are involved in many physiological processes such as cell growth, root formation, seed germination and fruit ripening [1]. Moreover, these compounds are considered secondary metabolites involved in the chemical defense of plants against predators, pathogens, environmental stresses and in plant-plant interferences [2].

Nowadays, phenolic compounds represent a unique and a functional place, composed of bioactive products, present in plant-derived foods and beverages and included in the formulations of well-marketed cosmetic and parapharmaceutical products [3]. Furthermore, polyphenols exhibit various biological activities such as anticancer [4], antioxidant [5], antimicrobial [6] and anti-inflammatory activities [7]. Therefore, in recent years, the determination of phenolic compounds concentrations in fruits [8] [9], vegetables [10] and some aromatic and medicinal plants [11] [12] has been of increasing interest in the scientific community as well as among health professionals and business partners.

It is well known that the content of phenolic compounds could be influenced by environmental conditions, such as season [13] [14], sampling period and geographic origin [15], precipitations and temperatures [16], and soil type [17]. Additionally, there are several experimental factors that can influence the rate of extraction and the quality of extracted bioactive phenolic compounds. These factors include extraction method, solvent type used and concentration [18], particle size of medicinal plants, temperature and $\mathrm{pH}$ of extraction [19], extraction time [20], number of extractions repetition [1] and solvent-to-sample ratio [21].

In order to recover bioactive compounds from plant raw materials, extraction is widely used and it constitutes the first important step [22]. Different solvents and techniques are used for the extraction of polyphenols from plants [23] [24]. However, there is no one standard extraction method used to extract phenolic compounds from plant materials because of their complexity and their interaction with other bioactive compounds [25]. Furthermore, each plant material has its unique properties, in term of phenolic extraction; different plants may require different extraction conditions to achieve the optimum recovery of phenolic compounds [26].

The family Lamiaceae includes aromatic and medicinal plants, which are used in traditional medicine, although Lamiaceae species are well known for their volatile oil content, their therapeutic activities and other properties. This reflects the existence of other chemical components, such as the polyphenols. Marrubium vulgare L. commonly known in Europe as "White horehound", and in the Mediterranean region as "Marute" or as "Merriouet" in Algeria, is a perennial herb of Lamiaceae family, naturalized in North and South America, and Western Asia [27]. In Algeria, M. vulgare is used in folk medicine to treat several digestive diseases, diarrhea, as well as diabetes, rheumatism, acute or chronic bronchitis, cough, asthma and other respiratory infections [28]. Earlier, phytochemical investigation of $M$. vulgare have led to the characterization of a very complex metabolic pattern, containing, among other secondary metabolites, diterpenes [29], phenyl propanoids esters [30], tannins [31] and flavonoids [32]. Several activities, traditionally attributed to M. vulgare, were approved by intensive modern research and clinical trials, such as hypoglycemic [33], vasorelaxant and antihypertensive [29], analgesic [34], antidiabetic [35], anti-inflammatory [36], and antioxidant properties [37].

However, to the best of our knowledge, optimizing the extraction of phenolic compounds from M. vulgare leaves, using different extraction conditions and response surface methodology (RSM), has not been reported yet. Hence, the purpose of the current study was to investigate the effects of different extracting conditions (organic solvent type, concentration of organic solvent, temperature and time) on the extraction of phenolic compounds (total phenolic content, TPC; total flavonoid content, TFC; and condensed tannins content, CTC) from M. vulgare leaves.

\section{Material and Methods}

\subsection{Plant Material}

Leaves of M. vulgare were collected in April 2012, from Tessala Mountain (north-western Algeria, semi-arid 
climate) at the level of a station which latitudinal coordinates $35^{\circ} 16^{\prime} 33^{\prime \prime} \mathrm{N}$, and longitudinal $0^{\circ} 46^{\prime} 27^{\prime \prime} \mathrm{W}$, altitude $596 \mathrm{~m}$. The identification of plant specimen was done by Professor Z. Mehdadi and put at the Laboratory of Vegetal Biodiversity: Conservation and Valorization (Faculty of Natural and Life Sciences, Djillali Liabes University of Sidi Bel-Abbes, Algeria).

Upon arrival at the laboratory, samples were thoroughly rinsed with distilled water, dried in the dark for three weeks at room temperature and crushed with the cutting mill. The powdered samples were packaged into a linear-low-density polyethylene (LLDPE) film and stored in dark at room temperature for further experiments.

\subsection{Extract Preparation}

Two grams of leaf powder M. vulgare were extracted using $20 \mathrm{ml}$ of extraction solvent with different concentrations, introduced in conical flask of capacity $100 \mathrm{ml}$ sealed with parafilm and wrapped with aluminum foil to prevent solvent loss and exposure to light. Therefore, the mixture was stirred at $150 \mathrm{rpm}$ in bath water with controlling temperature at a constant speed (level 8) for a particular duration. After completing the extraction process, the $M$. vulgare extract was filtered using Whatman No. 1 filter paper into amber bottle for analysis without storage overnight, in order to obtain a clear crude extract solution.

To determine the optimal conditions for phenolic extraction from $M$. vulgare leaves, the extraction conditions were set according to the experimental design described below:

- Organic solvents type: three kinds of organic solvents (methanol, ethanol and acetone) were selected. Distilled water was tested as control. The selection of the three extraction solvents is made firstly after several (about one hundred) referenced protocols in terms of quantification of phenolic compounds and secondly from the viewpoint of the availability of the chemicals used;

- Solvent concentrations: four concentrations $(20 \%, 40 \%, 60 \%$ and $80 \%$; $/ \mathrm{v})$ were prepared in distilled water;

- Extraction temperatures: six temperatures $\left(20^{\circ} \mathrm{C}, 25^{\circ} \mathrm{C}, 30^{\circ} \mathrm{C}, 40^{\circ} \mathrm{C}, 50^{\circ} \mathrm{C}\right.$ and $\left.60^{\circ} \mathrm{C}\right)$ were used;

- Extraction times: six different times (30, 90, 180, 270, 360 and 450 min) were chosen.

\subsection{Total Phenolic Contents (TPC)}

TPC of M. vulgare extracts was determined using Folin-Ciocalteu reagent, according to method suggested by Li et al. [38] and slightly modified by Chew et al. [39]. Crude extracts were diluted 50 times with deionized water prior to analysis. $1 \mathrm{ml}$ of diluted extract was mixed with $1 \mathrm{ml}$ of diluted Folin-Ciocalteu reagent (10 times diluted with deionized water). After incubating the mixture at room temperature for $4 \mathrm{~min}, 0.8 \mathrm{ml}$ of $7.5 \%(\mathrm{w} / \mathrm{v})$, sodium carbonate anhydrous solution was added. The mixture was then vortexed for $10 \mathrm{~s}$ and incubated in the dark at room temperature during $2 \mathrm{~h}$. The absorbance of the mixture was measured against blank at $765 \mathrm{~nm}$ using UVi light spectrophotometer. Gallic acid with different concentrations (0-100-200-300-400-500 mg/l) was used to calibrate the standard curve. The calibration equation for gallic acid was $Y=0.0042 X-0.0178\left(R^{2}=\right.$ 0.9992). Each crude extract was analyzed in triplicate and the results were expressed in milligrams of gallic acid equivalents per gram of dry weight (mg GAE/g DW). Data were expressed as mean \pm standard deviation.

\subsection{Total Flavonoids Contents (TFC)}

TFC was determined using procedures described by Tan et al. [21]. The crude extract was diluted 10 times. An amount of $1.25 \mathrm{ml}$ deionised water followed by $75 \mu \mathrm{l}$ of $5 \%$ sodium nitrite (NaNO2), was added to $0.25 \mathrm{ml}$ of diluted crude extract in an aluminium foil-wrapped $15 \mathrm{ml}$ test tube. The mixture was left standing for 6 min before adding $150 \mu \mathrm{l}$ of $10 \%$ (w/v) aluminium chloride (AlCl3). The mixture was left standing for $5 \mathrm{~min}$ before adding $0.5 \mathrm{ml}$ of $1 \mathrm{M}$ sodium hydroxide $(\mathrm{NaOH})$ and $275 \mu \mathrm{l}$ of deionised water. The tip of the test tube was covered with parafilm and then mixed using vortex mixer for approximately $10 \mathrm{~s}$. The absorbance of the mixture was determined at $510 \mathrm{~nm}$ versus the prepared blank using Uvi light spectrophotometer. Catechin with different concentration (0 - 100 - 200 - $300-400-500 \mathrm{mg} / \mathrm{l}$ ) was used for calibration. The calibration equation for catechin was calculated as follow: $Y=0.0035 X-0.0062\left(R^{2}=0.9995\right)$. Each crude extract was analyzed in triplicate and the results were expressed in milligrams of catechin equivalents per gram of dry weight (mg CE/g DW). Data were expressed as mean \pm standard deviation.

\subsection{Total Flavonoid Contents (TFC)}

TFC was determined using procedures described by Tan et al. [21]. The crude extract was diluted 10 times. An 
amount of $1.25 \mathrm{ml}$ deionised water followed by $75 \mu \mathrm{l}$ of $5 \%$ sodium nitrite $\left(\mathrm{NaNO}_{2}\right)$, was added to $0.25 \mathrm{ml}$ of diluted crude extract in an aluminium foil-wrapped $15 \mathrm{ml}$ test tube. The mixture was left standing for 6 min before adding $150 \mu \mathrm{l}$ of $10 \%(\mathrm{w} / \mathrm{v})$ aluminium chloride (AlCl3). The mixture was left standing for $5 \mathrm{~min}$ before adding $0.5 \mathrm{ml}$ of $1 \mathrm{M}$ sodium hydroxide $(\mathrm{NaOH})$ and $275 \mu \mathrm{l}$ of deionised water. The tip of the test tube was covered with parafilm and then mixed using vortex mixer for approximately $10 \mathrm{~s}$. The absorbance of the mixture was determined at $510 \mathrm{~nm}$ versus the prepared blank using Uvi light spectrophotometer. Catechin with different concentration (0 - 100 - 200 - 300 - 400 - $500 \mathrm{mg} / \mathrm{l})$ was used for calibration. The calibration equation for catechin was calculated as follow: $Y=0.0035 X-0.0062\left(R^{2}=0.9995\right)$. Each crude extract was analyzed in triplicate and the results were expressed in milligrams of catechin equivalents per gram of dry weight (mg CE/g DW). Data were expressed as mean \pm standard deviation.

\subsection{Condensed Tannins Contents (TFC)}

CTC assay was performed according to the method described by Chew et al. [39]. $0.5 \mathrm{ml}$ undiluted crude extract was firstly mixed with $3 \mathrm{ml}$ of vanillin reagent ( $4 \%$, w/v, in absolute methanol), followed by addition of $1.5 \mathrm{ml}$ of concentrated $\mathrm{HCl}$ (37\%). After that, the mixture was stored in the dark at room temperature for $15 \mathrm{~min}$. The absorbance of mixture was measured at $500 \mathrm{~nm}$ against blank using Uv light spectrometer. Each undiluted crude extract was measured in triplicate. Catechin with different concentrations (0 - 100 - 200 - 300 - 400 - 500 mg/l) was used for calibration of standard curve. The calibration equation for catechin was calculated using the formula $Y=0.0021 X-0.0143\left(R^{2}=0.997\right)$. Each crude extract was analyzed in triplicate and the results were expressed in milligrams of catechin equivalents per gram of dry weight (mg CE/g DW). Data were expressed as mean \pm standard deviation.

\subsection{Statistical Analysis}

In order to control the influence of extraction conditions (solvent type, solvent concentration, extraction time, and extraction temperature) on the mean concentrations of each phenolic compound, ANOVA, with more classification criteria, using Fisher's least significant difference test and the significant differences at the 5\% level, were calculated. The difference was considered as not significant when $P>0.05$, significant when ${ }^{*} P \leq 0.05$, and highly significant for ${ }^{* *} P \leq 0.01$ and extremely significant for ${ }^{* * *} P \leq 0.001$. These analyzes were performed using Minitab 16. Tukey's test was also performed for pair-wise comparisons at the $5 \%$ level.

To determine possible correlation among polyphenols concentrations and extraction conditions, PCA was used. This statistical tool is dedicated for data exploration, which allows the reduction of the number of quantitative variables to a small number of components. Moreover, using PCA, interrelationships between different variables could be seen, and detected and sample patterns, groupings, similarities or differences could be interpreted [40]. A matrix is prepared using XLSTAT 2012 software, by taking polyphenols concentrations as observations and extraction conditions as variables.

Optimal conditions for the extraction of phenolic compounds from $M$. vulgare leaves were obtained using response surface methodology (RSM) [41] [42]. This method is adopted for each type of phenolic compound with the solvent giving the highest experimental concentration. The independent variables studies were solvent concentration $\left(X_{1}\right)$, extraction temperature $\left(X_{2}\right)$ and extraction time $\left(X_{3}\right)$; while the dependent variable ( $Y$ : response variable) measured was the contents of phenolic compound. To obtain the best combination of independent variables giving a maximum percentage of adjusted $\mathrm{R}^{2}$, a best subsets regression is performed using Minitab 16 software. Thus, the regression equation of the model is obtained by an analysis of general regression. Finally, the optimum polyphenols contents and extraction conditions are obtained by introducing the regression equation in Maple 6 software. The experimental and predicted values of polyphenols contents and extraction conditions were compared, in order to determine the validity of the model.

\section{Results and Discussion}

Results of total phenolic, total flavonoids, and condensed tannins amounts are shown in Figure 1 and Figure 2. The influence of extraction's conditions used on phenolic compounds amounts obtained using ANOVA, with more classification criteria, is presented in Table 1. 
Table 1. Analysis of variance (ANOVA) with more classification criteria of quantified phenolic compounds.

\begin{tabular}{|c|c|c|c|c|c|}
\hline Source & Degree of freedom & Sum of Squares & Mean squares & F-value & $P$-value \\
\hline \multirow{3}{*}{1} Solvent type & \multirow[t]{3}{*}{ 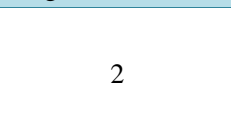 } & $40326.1^{\mathrm{TPC}}$ & $20163.1^{\text {TPC }}$ & $262.15^{\mathrm{TPC}}$ & $<0.0001^{* * *}$ \\
\hline & & $2326.12^{\mathrm{TFC}}$ & $1163.06^{\mathrm{TFC}}$ & $274.61^{\mathrm{TFC}}$ & $<0.0001^{* * *}$ \\
\hline & & $43.14^{\mathrm{CTC}}$ & $21.57^{\mathrm{CTC}}$ & $\mathrm{UD}^{\mathrm{CTC}}$ & $<0.0001^{* * *}$ \\
\hline \multirow{3}{*}{2} Solvent concentration & \multirow{3}{*}{4} & $107832.8^{\mathrm{TPC}}$ & $26958.2^{\mathrm{TPC}}$ & $350.49^{\mathrm{TPC}}$ & $<0.0001^{* * *}$ \\
\hline & & $5132.83^{\mathrm{TFC}}$ & $1283.21^{\mathrm{TFC}}$ & $302.98^{\mathrm{TFC}}$ & $<0.0001^{* * *}$ \\
\hline & & $257.24^{\mathrm{CTC}}$ & $64.31^{\text {СТС }}$ & $\mathrm{UD}^{\mathrm{CTC}}$ & $<0.0001^{* * *}$ \\
\hline \multirow{3}{*}{3} Extraction time & \multirow{3}{*}{5} & $45983.2^{\mathrm{TPC}}$ & $9196.6^{\mathrm{TPC}}$ & $119.57^{\mathrm{TPC}}$ & $<0.0001^{* * *}$ \\
\hline & & $111.09^{\mathrm{TFC}}$ & $22.22^{\mathrm{TFC}}$ & $5.25^{\mathrm{TFC}}$ & $<0.0001^{* * *}$ \\
\hline & & $592.16^{\mathrm{CTC}}$ & $118.43^{\mathrm{CTC}}$ & $\mathrm{UD}^{\mathrm{CTC}}$ & $<0.0001^{* * *}$ \\
\hline \multirow{3}{*}{4} Extraction temperature & \multirow{3}{*}{5} & $553938.7^{\mathrm{TPC}}$ & $110787.7^{\mathrm{TPC}}$ & $1440.39^{\mathrm{TPC}}$ & $<0.0001^{* * * *}$ \\
\hline & & $39821.11^{\mathrm{TFC}}$ & $7964.22^{\mathrm{TFC}}$ & $1880.44^{\mathrm{TFC}}$ & $<0.0001^{* * *}$ \\
\hline & & $10589.43^{\mathrm{CTC}}$ & $2117.89^{\mathrm{CTC}}$ & $\mathrm{UD}^{\mathrm{CTC}}$ & $<0.0001^{* * *}$ \\
\hline $\multirow{3}{*}{1}^{*}\{2\}$ & \multirow{3}{*}{8} & $31097.1^{\mathrm{TPC}}$ & $3887.1^{\mathrm{TPC}}$ & $50.54^{\mathrm{TPC}}$ & $<0.0001^{* * *}$ \\
\hline & & $1654.30^{\mathrm{TFC}}$ & $206.79^{\mathrm{TFC}}$ & $48.82^{\mathrm{TFC}}$ & $<0.0001^{* * *}$ \\
\hline & & $10.91^{\text {СТС }}$ & $1.36^{\mathrm{CTC}}$ & $\mathrm{UD}^{\mathrm{CTC}}$ & $<0.0001^{* * *}$ \\
\hline $\multirow{3}{*}{1}^{*}\{3\}$ & \multirow{3}{*}{10} & $7922.1^{\mathrm{TPC}}$ & $792.2^{\mathrm{TPC}}$ & $10.30^{\mathrm{TPC}}$ & $<0.0001^{* * *}$ \\
\hline & & $54.86^{\mathrm{TFC}}$ & $5.49^{\mathrm{TFC}}$ & $1.30^{\mathrm{TFC}}$ & $=0.235^{\mathrm{NS}}$ \\
\hline & & $2.59^{\mathrm{CTC}}$ & $0.26^{\mathrm{CTC}}$ & $\mathrm{UD}^{\mathrm{CTC}}$ & $<0.0001^{* * *}$ \\
\hline $\multirow{3}{*}{1}^{*}\{4\}$ & \multirow{3}{*}{10} & $14801.5^{\mathrm{TPC}}$ & $1480.1^{\mathrm{TPC}}$ & $19.24^{\mathrm{TPC}}$ & $<0.0001^{* * * *}$ \\
\hline & & $2422.48^{\mathrm{TFC}}$ & $242.25^{\mathrm{TFC}}$ & $57.20^{\mathrm{TFC}}$ & $<0.0001^{* * *}$ \\
\hline & & $0.00^{\mathrm{CTC}}$ & $0.00^{\mathrm{CTC}}$ & $\mathrm{UD}^{\mathrm{CTC}}$ & $<0.0001^{* * *}$ \\
\hline $\multirow{3}{*}{2}^{*}\{3\}$ & \multirow{3}{*}{20} & $35664.5^{\mathrm{TPC}}$ & $1783.2^{\mathrm{TPC}}$ & $23.18^{\mathrm{TPC}}$ & $<0.0001^{* * *}$ \\
\hline & & $599.22^{\mathrm{TFC}}$ & $29.96^{\mathrm{TFC}}$ & 7.07TFC & $<0.0001^{* * *}$ \\
\hline & & $100.97^{\text {СТС }}$ & $5.05^{\mathrm{CTC}}$ & $\mathrm{UD}^{\mathrm{CTC}}$ & $<0.0001^{* * *}$ \\
\hline $\multirow{3}{*}{2}^{*}\{4\}$ & \multirow{3}{*}{20} & $48446.9^{\mathrm{TPC}}$ & $2422.3^{\mathrm{TPC}}$ & $31.49^{\mathrm{TPC}}$ & $<0.0001^{* * *}$ \\
\hline & & $7603.54^{\mathrm{TFC}}$ & $380.18^{\mathrm{TFC}}$ & $89.76^{\mathrm{TFC}}$ & $<0.0001^{* * *}$ \\
\hline & & $233.26^{\mathrm{CTC}}$ & $11.66^{\mathrm{CTC}}$ & $\mathrm{UD}^{\mathrm{CTC}}$ & $<0.0001^{* * *}$ \\
\hline $\multirow{3}{*}{3}^{*}\{4\}$ & \multirow{3}{*}{25} & $18241.9^{\mathrm{TPC}}$ & $729.7^{\mathrm{TPC}}$ & $9.49^{\mathrm{TPC}}$ & $<0.0001^{* * *}$ \\
\hline & & $767.42^{\mathrm{TFC}}$ & $30.70^{\mathrm{TFC}}$ & $7.25^{\mathrm{TFC}}$ & $<0.0001^{* * *}$ \\
\hline & & $92.06^{\mathrm{CTC}}$ & $3.68^{\mathrm{CTC}}$ & $\mathrm{UD}^{\mathrm{CTC}}$ & $<0.0001^{* * *}$ \\
\hline $\multirow{3}{*}{1}^{*}\{2\}^{*}\{3\}$ & \multirow{3}{*}{40} & $8775.9^{\mathrm{TPC}}$ & $219.4^{\mathrm{TPC}}$ & $2.58^{\mathrm{TPC}}$ & $<0.0001^{* * *}$ \\
\hline & & $314.37^{\mathrm{TFC}}$ & $7.86^{\mathrm{TFC}}$ & $1.86^{\mathrm{TFC}}$ & $=0.003^{* *}$ \\
\hline & & $1.26^{\mathrm{CTC}}$ & $0.03^{\mathrm{CTC}}$ & $\mathrm{UD}^{\mathrm{CTC}}$ & $<0.0001^{* * *}$ \\
\hline $\multirow{3}{*}{1}^{*}\{2\}^{*}\{4\}$ & & $18002.2^{\mathrm{TPC}}$ & $450.1^{\mathrm{TPC}}$ & $5.85^{\mathrm{TPC}}$ & $<0.0001^{* * *}$ \\
\hline & 40 & $3061.91^{\mathrm{TFC}}$ & $76.55^{\mathrm{TFC}}$ & $18.07^{\mathrm{TFC}}$ & $<0.0001^{* * *}$ \\
\hline & & $0.00^{\mathrm{CTC}}$ & $0.00^{\mathrm{CTC}}$ & $0.00^{\mathrm{CTC}}$ & $<0.0001^{* * *}$ \\
\hline & & $5440.4^{\mathrm{TPC}}$ & $108.8^{\mathrm{TPC}}$ & $1.41^{\mathrm{TPC}}$ & $=0.050^{*}$ \\
\hline$\{1\}^{*}\{3\}^{*}\{4\}$ & 50 & $272.27^{\mathrm{TFC}}$ & $5.45^{\mathrm{TFC}}$ & $1.29^{\mathrm{TFC}}$ & $=0.116^{\mathrm{NS}}$ \\
\hline & & $0.00^{\mathrm{CTC}}$ & $0.00^{\mathrm{CTC}}$ & $\mathrm{UD}^{\mathrm{CTC}}$ & $<0.0001^{* * *}$ \\
\hline & & $46098.9^{\mathrm{TPC}}$ & $461.0^{\mathrm{TPC}}$ & $5.99^{\mathrm{TPC}}$ & $<0.0001^{* * *}$ \\
\hline$\{2\}^{*}\{3\}^{*}\{4\}$ & 100 & $1176.72^{\mathrm{TFC}}$ & $11.77^{\mathrm{TFC}}$ & $2.78^{\mathrm{TFC}}$ & $<0.0001^{* * *}$ \\
\hline & & $176.67^{\mathrm{CTC}}$ & $1.77^{\text {СTC }}$ & $\mathrm{UD}^{\mathrm{CTC}}$ & $<0.0001^{* * *}$ \\
\hline & & 15383.0 & 76.09 & $\mathrm{UD}^{\mathrm{TPC}}$ & $<0.0001^{* * *}$ \\
\hline$\{1\}^{*}\{2\}^{*}\{3\}^{*}\{4\}$ & 200 & 847.06 & 4.24 & $\mathrm{UD}^{\mathrm{TFC}}$ & $<0.0001^{* * *}$ \\
\hline & & 0.00 & 0.00 & $\mathrm{UD}^{\mathrm{CTC}}$ & $<0.0001^{* * *}$ \\
\hline
\end{tabular}

UD: undefined (the denominator of Fisher's test is null or undefined). 

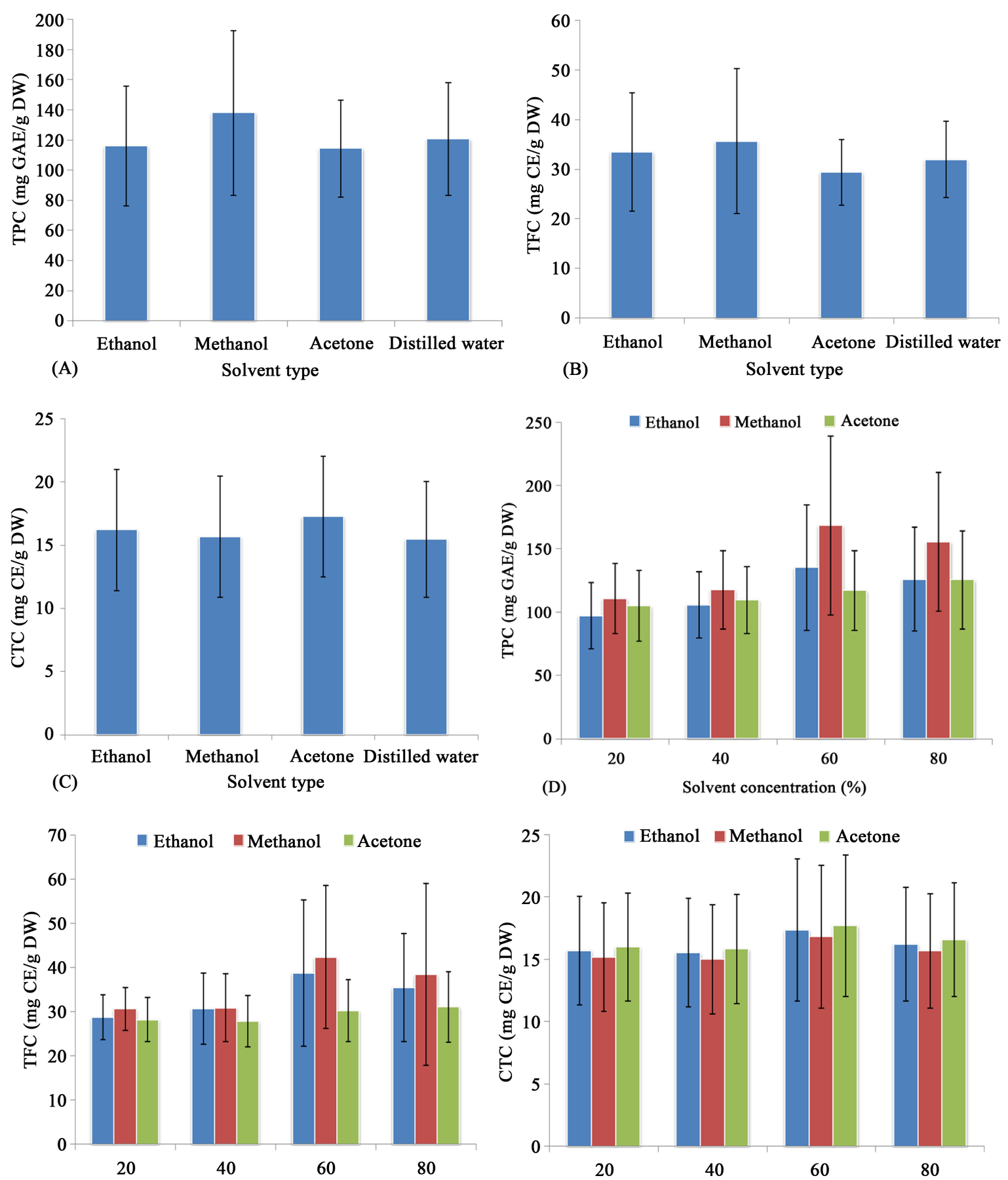

(E)

Solvent concentration (\%)

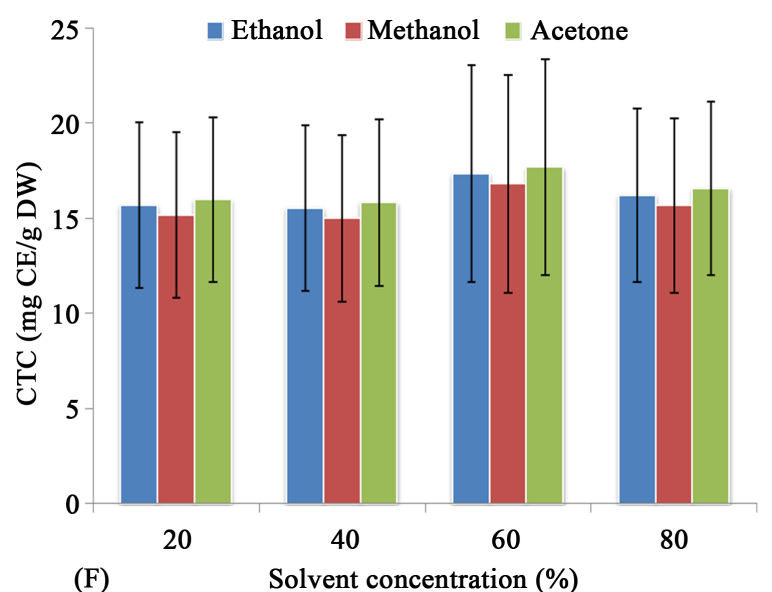

Figure 1. Effects of solvent type ((A), (B), (C)) and solvent concentration ((D), (E), (F)) on TPC, TFC and CTC extracted from $M$. vulgare leaves.

\subsection{Effect of Solvent Type on Extraction of Phenolic Compounds}

The choice of extraction solvents is important for complex food samples. They allow determining the amount and the type of phenolic compounds to extract. Organic solvents, particularly acetone, ethanol and methanol are the most commonly used in polyphenols extraction from botanical materials [43].

Our results showed that methanol (137.79 $\pm 54.62 \mathrm{mg} \mathrm{GAE} / \mathrm{g})$ was significantly high effective $\left({ }^{* * * *} \mathrm{P}<0.001\right)$ 

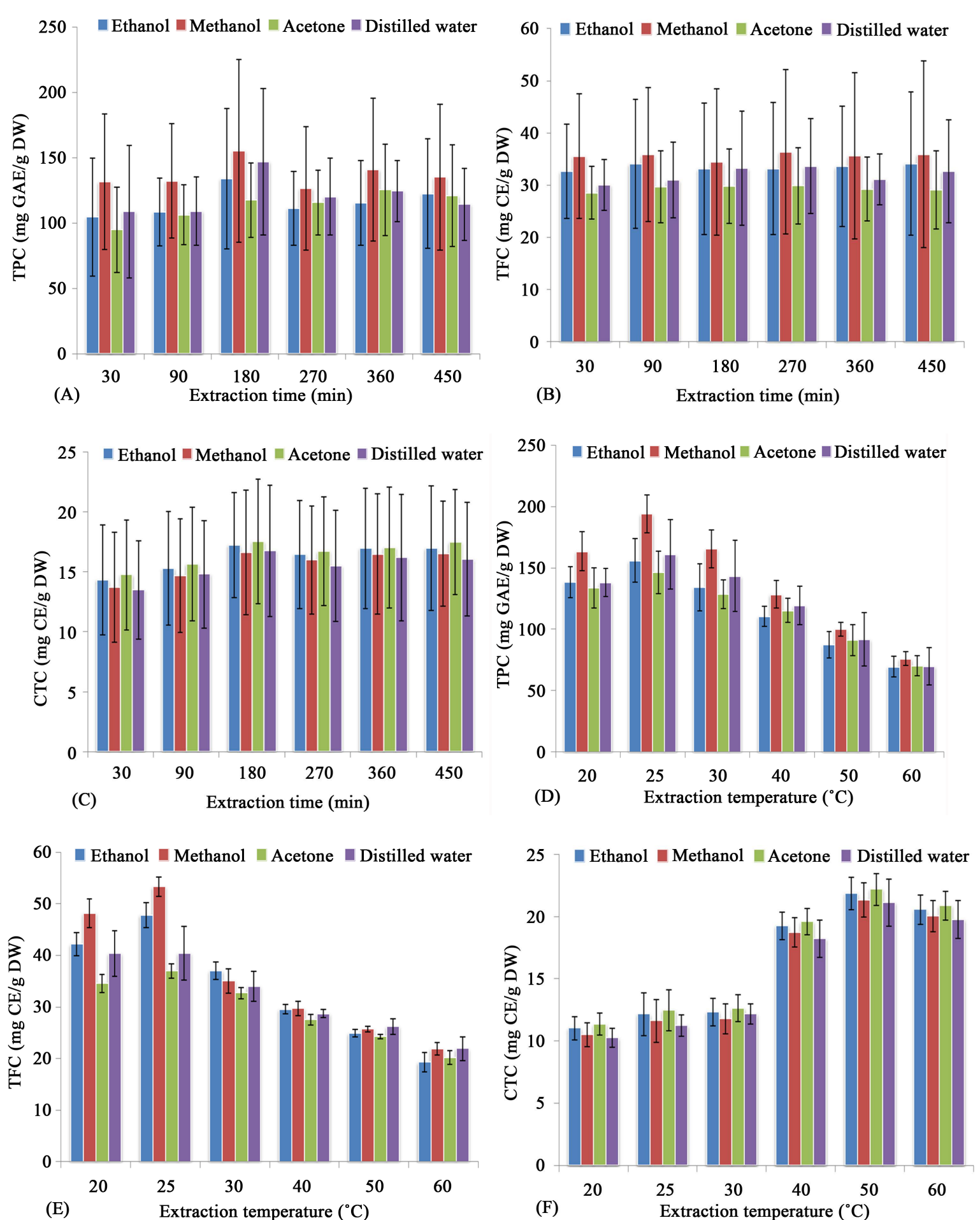

Figure 2. Effects of extraction time ((A), (B), (C)) and extraction temperature ((D), (E), (F)) on TPC, TFC and CTC extracted from $M$. vulgare leaves.

when compared with all other solvent systems used in extracting TPC from M. vulgare leaves, as shown in Figure 1(A). Methanol has been considered as an ideal solvent for the TPC extraction from green walnut fruits [44], Zingiber officinalis leaves [45], Tamarix aphylia leaves [46] and Artemisia annua leaves [47]. Several studies confirmed that TPC depends on organic solvent polarity and methanol is one of the most suitable solvents for 
the extraction of TPC from plants [48] [49]. Mohammedi and Atik [46] reported that the high polarity of methanol, estimated at 6.6, compared to other organic solvents, plays a key role in increasing phenolic solubility. However, Kong et al. [50] found that TPC in methanolic extracts, obtained from Pouteria campechiana fruit parts, was about $23 \%$ to $45 \%$ lower than the ethanolic extracts.

Methanol permitted to obtain the highest extraction levels of TFC (35.64 $\pm 14.61 \mathrm{mg} \mathrm{CE} / \mathrm{g})$ from M. vulgare leaves (Figure 1(B)). Furthermore, a significant difference $\left({ }^{* * *} \mathrm{P}<0.001\right)$ was found between the type of organic solvents used. Similar results were observed for Moringa oleifera and Aloe barbadensis leaves [51], Euphorbia helioscopia leaves, steams and flowers [52]. Our results agree with previous studies, which found that ethanol was less effective than methanol for extracting TFC [53] [54]. In contrast, Settharaksa et al. [55] have found that using water to extract solvent from some Thai medicinal plants, was better than using ethanolic and methanolic solvents to extract TFC. Ghasemzadeh et al. [45] reported that extraction of TFC from Zingiber officinale leaves, using methanol, was about 3 times higher when using acetone and 4 times higher when using hexane. Spigno et al. [56] suggested that high level of TPC obtained using methanol, could be explained by the fact that this solvent allows a good solubility of flavonoids' hydroxyl groups.

A maximum level of CTC (17.24 $\pm 4.77 \mathrm{mg}$ CE/g) was reached using acetone, as shown in Figure $1(\mathrm{C})$. There was a high significant difference between the four tested solvents $\left({ }^{* * *} P<0.001\right)$. Our results agree with those of Trabelsi et al. [18] who found that maximum CTC level, from Limoniastrum monopetalum leaves, was obtained when acetone solvent was used. Similarly, in other studies performed by Wina et al. [57] and Mazandarani et al. [58], acetone was found to be the most effective solvent extracting CTC from Acacia mangium barks and Onosma dichroanthum roots, respectively. According to Antwi-Boasiako and Animapauh [59], the four solvents tested in the current study, especially acetone and methanol were the best extraction solvents of CTC from the barks of three tropical hardwoods. Additionally, Uma et al. [60] showed that acetone was the most effective solvent for extraction of condensed tannins as tannins have a relatively high molecular weight.

\subsection{Effect of Solvent Concentration on Extraction of Phenolic Compounds}

Mixtures of alcohols with different proportions of water have shown to be more effective in extracting phenolic compounds compared to mono-component solvent system [25]. Addition of small quantity of water to organic solvent usually leads to a more polar medium, which facilitates the polyphenols extraction [56].

We observed that maximum rate of TPC (168.41 $\pm 70.60 \mathrm{mg}$ GAE/g), extracted from $M$. vulgare leaves, was obtained when aqueous methanol was used at $60 \%$ (Figure 1(D)). However, there were high significant differences $\left({ }^{* * *} P<0.001\right)$ in TPC among the various concentrations. Our results are in line with those found by Chan et al. [61] and Chew et al. [39] who found that $60 \%$ aqueous methanol gave the best effectiveness extracting TPC from Citrus hystrix peels and Centella asiatica leaves, respectively. Yilmaz and Toledo [62] reported that aqueous mixtures of methanol, ethanol or acetone were better than a mono-component solvent for the extraction of TPC from Muscadine seeds.

The highest value of TFC (42.40 $\pm 16.22 \mathrm{mg} \mathrm{CE} / \mathrm{g})$, as shown in Figure 1(E), was obtained, when we used 60\% of aqueous methanol and was significantly different $\left({ }^{* * *} P<0.001\right)$ compared to the other studied concentrations. In contrast, aqueous methanol at $80 \%$ was the best concentration for Calendula officinalis flowers [63] and aqueous ethanol at $80 \%$ from the leaves of Limoniastrum monopetalum [18], Bauhinia monandra [64] and Callicarpa nudiflora [41]. Musa et al. [65] confirmed that the mixture of an aqueous solvent (distilled water) with an organic solvent (methanol and ethanol) improves the flavonoids yield comparing to water or organic solvent used separately.

Sixty percent $(60 \%)$ acetone in water gave the highest value of CTC, which was $17.68 \pm 5.69 \mathrm{mg} \mathrm{CE} / \mathrm{g}$ (Figure 1(F)). Moreover, there were high significant $\left({ }^{* * *} P<0.001\right)$ differences in CTC values among the different concentrations used. Our data are in agreement with those reported by Downey and Hanlin [66] on grape skin. In other studies, it has been noticed that $80 \%$ aqueous acetone was the best concentration for CTC extraction from Limonium densiflorum shoots [67], 60\% aqueous methanol from Cichorium intybus L. roots, leaves, stems and seeds [68], and 80\% aqueous ethanol from the Chinese chestnut [69].

\subsection{Effect of Extraction Time on Extraction of Phenolic Compounds}

Extraction time represents another key parameter in optimizing the phenolic compounds extraction. In the literature, this parameter might be as short as few minutes or long up to 24 hours, depending on the phenolic com- 
pounds present in samples [70].

In this study, extraction time showed a significant effect $\left({ }^{* * *} \mathrm{P}<0.001\right)$ on the extraction of TPC from $M$. vulgare leaves. As shown in Figure 2(A), the highest value of TPC (155.16 $\pm 69.83 \mathrm{GAE} / \mathrm{g})$ was recorded using methanol for $180 \mathrm{~min}$. Chan et al. [61] demonstrated that $180 \mathrm{~min}$ represented the best extraction time for TPC from the peels of Citrus hystrix. In other studies, the best extraction time of TPC was estimated to 18 hours for black tea, Camellia sinensis [49], $90 \mathrm{~min}$ from grape pomace extracts [71], $45 \mathrm{~min}$ from Areca catechu seeds [72] and Azadirachta indica leaves [70]. Increased time of extraction beyond $180 \mathrm{~min}$ (270, 360 and $450 \mathrm{~min}$ ) induced a loss in TPC. Dent et al. [73] highly recommended that the extraction time, should not exceed $3 \mathrm{~h}$ for the extraction of TPC from Salvia officinalis leaves. Several authors stated that more the extraction time is long, less the content of polyphenols is obtained. This could be the result of loss of phenolic compounds, via oxidation, which might polymerize into insoluble compounds [26] [74]. Therefore, extraction time of TPC depends, not only, on maceration or agitation times, but also on several factors such as filtration time or the time spent during the evaporation of solvents [75].

The maximum of TFC concentration (39.95 $\pm 17.90 \mathrm{mg}$ CE/g) was obtained using methanol for $450 \mathrm{~min}$ as illustrated in Figure 2(B). Extraction time showed significant effect $\left({ }^{* * *} P<0.001\right)$ in TFC. However, 3 hours was considered to be the best extraction time for TFC from Callicarpa nudiflora leaves [46] and from some thyme varieties [76]. Additionally, $30 \mathrm{~min}$ has been shown to be the most favorable extraction time for TFC from Gynura medica leaves [77].

180 min was the longest extraction time, using acetone, for CTC (Figure 2(C)) with a maximum rate of $17.51 \pm$ $5.18 \mathrm{CE} / \mathrm{g}$. A high significant difference $\left({ }^{* * * *} \mathrm{P}<0.001\right)$ was obtained in CTC among different extraction times. Our results agree with those obtained by Zhekova and Pavlov [76] on some thyme varieties. In other works, the best extraction time was of 120 min for mangosteen fruits [78], 150 min for Parkia clappertoniana husks [79], 80 min for Cichorium intybus different organs [67], and 20 min for Punica granatum peels [80].

\subsection{Effect of Extraction Temperature on Extraction of Phenolic Compounds}

The effectiveness of extraction process of phenolic compounds is largely regulated by different experimental parameters particularly by the extraction temperature [81]. An increase of temperature is mainly due to an increase of the diffusion rate and solubility of the extracted substances. On the other hand, it should be taken into account, that some important biological active substances, such as TPC are damaged at high temperatures [82].

The extraction of TPC, as shown in Figure 2(D), was optimal when methanol was used at $25^{\circ} \mathrm{C}$. In this case, $194.16 \pm 15.45 \mathrm{mg}$ GAE/g DW were obtained with high significant difference $\left({ }^{* * *} P<0.001\right)$ and between different temperatures. Similar to our finding, $25^{\circ} \mathrm{C}$ was the most optimal extraction temperature for TPC from Lawsonia inermis leaves [60] and Azadirachta indica leaves [70]. Extension of extraction temperature beyond $25^{\circ} \mathrm{C}$ led to an important decrease in TPC. However, it should be noticed that increasing the extraction temperature, beyond certain values, might promote possible concurrent decomposition of phenolic compounds, which were already mobilized at lower temperature. Furthermore, this elevation of temperature can even lead to the breakdown of phenolic compounds that remained in the plant matrix [83] [84]. Hence, heating may affect the polyphenolic composition in many cases; therefore, high-temperature drying should be avoided as much as possible [2]. Usually, TPC extraction is used at room temperature $\left(\approx 25^{\circ} \mathrm{C}\right)$ to avoid the degradation of phenolic compounds [25]. However, in other experiments, the optimal extraction temperature for TPC was found more elevated and estimated to $40^{\circ} \mathrm{C}$ for Citrus hystrix peels [61], $100^{\circ} \mathrm{C}$ for Areca catechu seeds [72], $65^{\circ} \mathrm{C}$ for Centella asiatica leaves [39] and Orthosiphon stamineus stems and leaves [85], and $90^{\circ} \mathrm{C}$ for Moringa oleifera leaves [86].

A maximum of TFC rate $(53.31 \pm 1.83 \mathrm{CE} / \mathrm{g})$ was obtained at $25^{\circ} \mathrm{C}$ using methanol as solvent (Figure 2(E)). In the current investigation we found that extraction temperature significantly $\left({ }^{* * * *} P<0.001\right)$ affected the TFC extraction. However, in other researches, the highest extraction temperature was fixed at $90{ }^{\circ} \mathrm{C}$ for Callicarpa nudiflora leaves [41] and $60^{\circ} \mathrm{C}$ from some thyme varieties [76]. Like TPC, the extension of extraction temperature higher than $25^{\circ} \mathrm{C}$ led to an important decrease in TFC. However, the temperature conditions during the extraction procedures of flavonoids have to be carefully adjusted because of the possibility of thermal degradation of flavonoid derivatives, especially hydroxyl groups [87] [88]. In addition, mild heating was also found to have the ability to soften the plant tissues, to weaken the cell wall integrity, and thus to favor the release of bound phenolic compounds [56] [89]. 
As shown in Figure 2(F), the maximum of CTC rate $(22.18 \pm 1.27 \mathrm{CE} / \mathrm{g})$ was reached when acetone was used as a solvent and when the extraction temperature was about $50^{\circ} \mathrm{C}$. We observed a significant difference $\left({ }^{* * *} \mathrm{P}<0.001\right)$ in CTC between the extraction temperatures. Our results agree with those of Zam et al. [80] on Punica granatum peels. In other studies, the best extraction temperature was slightly elevated compared to those we obtained: $80^{\circ} \mathrm{C}$ for mangosteen fruits [78], $70^{\circ} \mathrm{C}$ Parkia clappertoniana husks [79] and $60^{\circ} \mathrm{C}$ for some thyme varieties [73]. Unlike the obtained results for TPC and TFC, the extension of extraction temperature beyond $25^{\circ} \mathrm{C}$ led to a significant increase in CTC. Al-Farsi and Lee [90] reported that elevated temperature could stimulate the CTC extraction by increasing both diffusion coefficient and solubility of condensed tannins in extraction solvent. Besides that, intense heat from solvent allowed the release of cell wall phenolics and bounded phenolics by breaking down cellular constituents [91] and consequently, increasing the phenolic yield in extract. Moreover, Juntachote et al. [89] reported that elevated extraction temperature would increase, on one hand, the mass transfer of condensed tannins, and on the other hand, it would reduce the solvent viscosity and surface tension and, promotes the extraction of phenolic compounds.

\subsection{Principal Component Analysis (PCA)}

PCA aimed to diminish the size of data collected into a reduced number of components to examine the possible grouping of phenolic compounds according to the different extraction conditions. The first factor, PC1 presented $85.55 \%$ of variance accounted for, whereas, the second one, PC2 presented $10.86 \%$. With the two first PCs, the explained variance accumulated was of $96.41 \%$. This great value means that nearly all the variance contained in the original data was explained by just using the first new coordinates. By layering variables projection circle on the observations scatter plot, two groups were obtained as shown in the PCA plot (Figure 3):

- Group 1 (Gr1) on the positive side of PC1, formed by TPC and TFC with 0.932 and 0.958 as contributions, respectively. These phenolic compounds are related with ethanolic, methanolic and aqueous extracts at low temperatures $20^{\circ} \mathrm{C}$ and $25^{\circ} \mathrm{C}$; ET1, ET2, MT1, MT2, DWT1, DWT2 with respective contributions of 2.285; 3.040 ; 3.578; 4.596; 2.253 and 2.618;

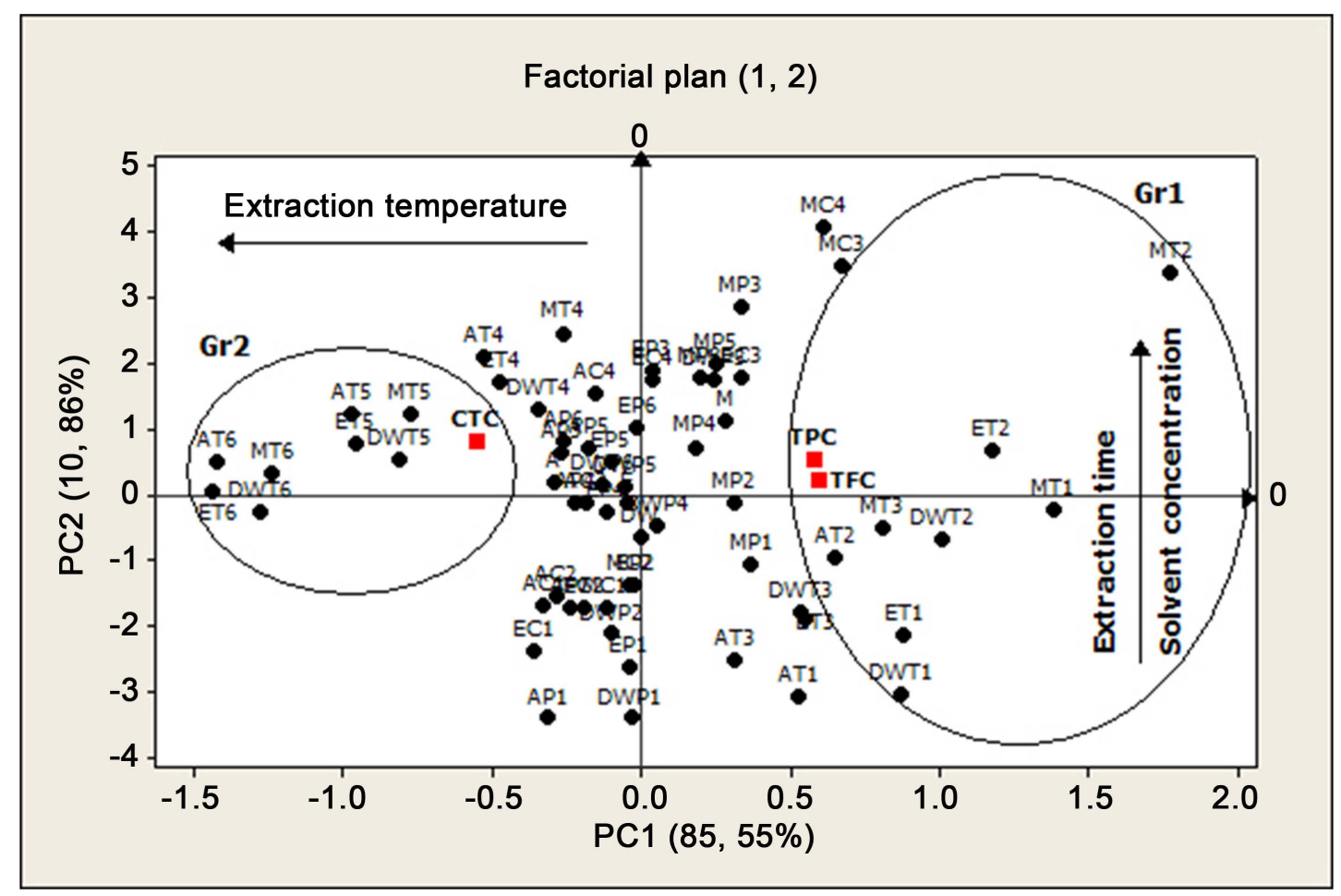

Figure 3. Principal component plot of PC1 and PC2. Gr: group; PC1: first principal component; PC2: second principal component; M: methanol; E: ethanol; DW: distilled water; A: acetone, C: concentration in \% (1: 20; 2: 40; 3: 60; 4: 80); T: temperature in ${ }^{\circ} \mathrm{C}(1: 20 ; 2: 25 ; 3: 30 ; 4: 40 ; 5: 50 ; 6: 60) ; P$ : time in min $(1: 30 ; 2: 90 ; 3: 180 ; 4: 270$; 5: 360; 6: 450). 
- Group 2 (Gr2) on the negative side of PC1, constituted by CTC with a contribution of -0.883 . This phenolic compound was associated to ethanolic, acetonic and aqueous extracts at high temperatures $50^{\circ} \mathrm{C}$ and $60^{\circ} \mathrm{C}$; ET5, ET6, AT5, AT6, DWT5, and DWT6 with contributions of $2.473 ; 3.705 ;-2.506 ;-3.661 ;-2.089$ and -3.290 , respectively.

- Moreover, considering the contributions of observations and variables on PC1, we defined two gradients:

- A horizontal gradient, moving from right to left of PC1, formed by the extraction temperature used, which explains the position of TPC and TFC right of PC1, correlated with low temperatures and the location of CTC to the left of PC1 in conjunction with high temperatures;

- A vertical gradient from the bottom to the top of PC1, constituted by the organic solvent concentration and the extraction time. This gradient explains the position of the three phenolic compounds measured at the top of PC1, correlated with high solvent concentrations (60\% for TPC and CTC, $80 \%$ for TFC) and high times (180 min for TPC and CTC, 270 min for TFC).

\subsection{Response Surface Methodology (RSM)}

The Response Surface Methodology (RSM) was plotted to study the effects of extraction conditions on phenolic compounds extraction from $M$. vulgare leaves. 3 D response surface plots are illustrated in Figure 4. The regression equation of the model selected, for each phenolic compound measured and their adjusted $\mathrm{R}^{2}$ was as follow:

- $\mathrm{TPC}=323.205-827.094 \mathrm{X} 1-4.2516 \mathrm{X} 2+0.015029 \mathrm{X} 3+843.115 \mathrm{X} 12+17.1341 \mathrm{X} 1 \mathrm{X} 2-13.5293$ $\mathrm{X} 2 \mathrm{X} 12-0.0615286 \mathrm{X} 1 \mathrm{X} 22$, with adjusted $\mathrm{R} 2=82.03 \%$,

- $\mathrm{TFC}=32.4239+31.9683 \mathrm{X} 1+0.42576 \mathrm{X} 2+0.0308808 \mathrm{X} 3+98.4907 \mathrm{X} 12-0.0108914 \mathrm{X} 22-2.96617$ $\mathrm{X} 1 \mathrm{X} 2-0.00163763 \mathrm{X} 3 \mathrm{X} 2-0.00122396 \mathrm{X} 1 \mathrm{X} 3 \mathrm{X} 2+0.0702683 \mathrm{X} 3 \mathrm{X} 12-2.22016 \mathrm{X} 2 \mathrm{X} 12+2.10557 \mathrm{e}-5$ $\mathrm{X} 3 \mathrm{X} 22+0.0492972 \mathrm{X} 1 \mathrm{X} 32$, with adjusted $\mathrm{R} 2=77.61 \%$,
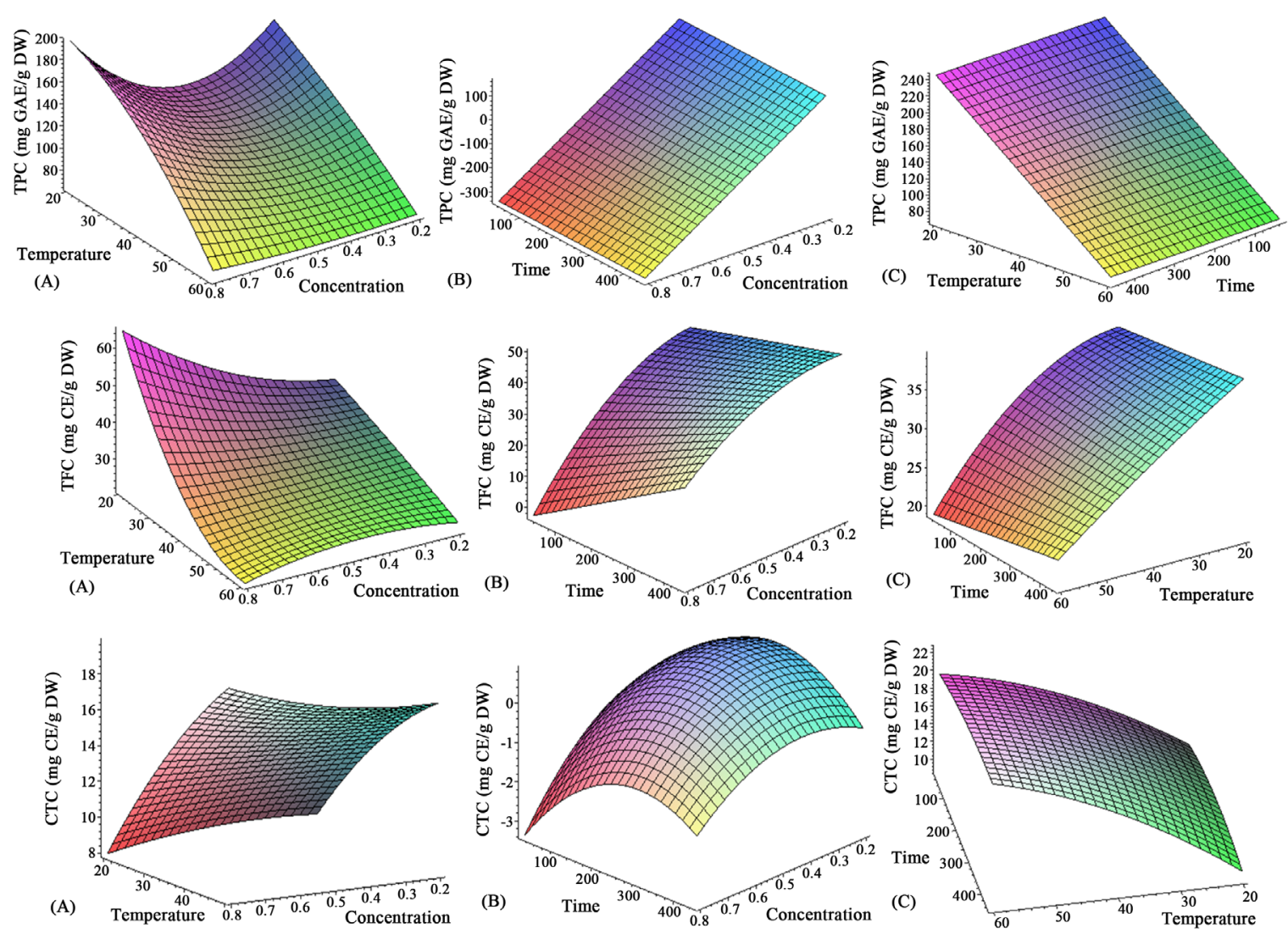

Figure 4. The 3D response surface plots representing the effects of (A) solvent concentration and extraction temperature; (B) solvent concentration and time extraction and (C) extraction temperature and extraction time on the extraction of phenolic compounds from $M$. vulgare leaves. 
- $\mathrm{CTC}=-2.19999+7.81089 \mathrm{X} 1+0.603279 \mathrm{X} 2+0.01403 \mathrm{X} 3-12.395 \mathrm{X} 12-0.00405521 \mathrm{X} 22-2.96468 \mathrm{e}-$ 5 X32-0.220734 X1X2 +0.00680008 X3X12 +0.388604 X2X12+2.36161e -7 X2X32, with adjusted $\mathrm{R} 2=90.62 \%$.

The comparison between the maximum experimental values of phenolic compounds and extraction conditions, and the predicted ones (Table 2), showed that the two sets of values were close. Indeed, the maximum value of TFC (experimental: $79.52 \mathrm{mg}$ CE/g; predicted: $79.46 \mathrm{mg} \mathrm{CE} / \mathrm{g}$ ) and CTC (experimental: $28.15 \mathrm{mg}$ CE/g, predicted: $20.81 \mathrm{mg} \mathrm{CE} / \mathrm{g}$ ) were obtained by the same experimental and predicted extraction conditions (TFC: aqueous methanol $80 \%$ at $20^{\circ} \mathrm{C}$ and for $450 \mathrm{~min}$; CTC: $60 \%$ at $50^{\circ} \mathrm{C}$ and for $180 \mathrm{~min}$ ). Concerning TPC, the maximum values of experimental and predicted contents and extraction conditions were different. The experimental values were of $293.34 \mathrm{mg} \mathrm{GAE} / \mathrm{g}$, obtained with aqueous methanol $60 \%$ at $25^{\circ} \mathrm{C}$ and for $180 \mathrm{~min}$. However, the predicted ones were of $204.75 \mathrm{mg} \mathrm{GAE} / \mathrm{g}$, obtained with aqueous methanol $80 \%$ at $20^{\circ} \mathrm{C}$ during $167 \mathrm{~min}$. Both, accounting experimental and predicted results indicated that the experimental model was valid. This implied that there was a high fit degree between the values observed in experiment and those predicted from the regression model. Hence, the response surface modeling could be applied effectively to predict extraction of phenolic compounds from M. vulgare leaves.

\section{Conclusions}

The results obtained in our study indicate that the experimental conditions tested (organic solvent type, solvent concentration, extraction time and extraction temperature) influence notably the values of TPC, TFC and CTC extracted from $M$. vulgare leaves, with extremely significant differences $\left({ }^{* * *} \mathrm{P}<0.001\right)$.

We were able to define the optimum extraction conditions too, for obtaining higher values of some phenolic compounds from $M$. vulgare leaves. Indeed, the optimum level of TPC (293 $\pm 14.60 \mathrm{mg} \mathrm{GAE} / \mathrm{g})$ was obtained using $60 \%$ aqueous methanol at $25^{\circ} \mathrm{C}$ for $180 \mathrm{~min}$, TFC (79.52 $\left.\pm 0.55 \mathrm{mg} \mathrm{CE} / \mathrm{g}\right)$ using $80 \%$ aqueous methanol at $20^{\circ} \mathrm{C}$ for $450 \mathrm{~min}$, and $\mathrm{CTC}(28.15 \pm 0.80 \mathrm{mg} \mathrm{CE} / \mathrm{g})$ with $80 \%$ aqueous acetone at $50^{\circ} \mathrm{C}$ for $450 \mathrm{~min}$. These levels highlight the richness of $M$. vulgare in these secondary metabolites. We conclude that this species remains poorly studied compared to other species belonging to the same taxonomic family (Lamiaceae) as thyme and sage.

Our results provide some confirmations on the effect of the variability of extraction procedures and assay on the amount of phenolic compounds recorded and reinforce previous works in this context.

This work is far from exhaustive as other experimental conditions can be tested, as the solid-to-solvent ratio, the number of extractions and the nature of the extraction method. Also, other extraction solvents (ethylene glycol, acetic acid and ethyl acetate), fractional extraction for many times or multistage extraction can be taken into consideration in our future works.

The impact of environmental conditions as the geographical region, altitude, exposure and the harvest season on the levels of polyphenols in $M$. vulgare is a promising perspective to this study and is still under investigation in our laboratory.

\section{Acknowledgements}

This research is a part of the Algerian National Project Research (entitled "Flora of Tessala Mountains: inventory, valorization and conservation”, code 1/u22/397), financially supported by the Algerian Ministry of High

Table 2. Optimum values of experimental and predicted polyphenols contents and extraction conditions.

\begin{tabular}{cccccccccc}
\hline & \multicolumn{2}{c}{$\begin{array}{c}\text { Polyphenols } \\
\text { concentrations }\end{array}$} & $\begin{array}{c}\text { Solvent } \\
\text { type }\end{array}$ & \multicolumn{2}{c}{$\begin{array}{c}\text { Solvent concentration } \\
\left(\mathrm{X}_{1}\right)\end{array}$} & \multicolumn{2}{c}{$\begin{array}{c}\text { Extraction } \\
\text { temperature }\left(\mathrm{X}_{2}\right)\end{array}$} & $\begin{array}{c}\text { Extraction } \\
\text { time }\left(\mathrm{X}_{3}\right)\end{array}$ \\
\hline & EV & PV & EV PV & EV & PV & EV & PV & EV & PV \\
TPC & 293.34 & 204.75 & Methanol & 60 & 80 & 25 & 20 & 180 & 167 \\
TFC & 79.52 & 79.46 & Methanol & 80 & 80 & 20 & 20 & 450 & 450 \\
CTC & 28.15 & 20.81 & Acetone & 60 & 60 & 50 & 50 & 180 & 180 \\
\hline
\end{tabular}

EV: experimental values; PV: predicted values. 
Education and Scientific Research. Also, the authors are grateful to Dr. Amel Latifi, Bacterial Chemistry Laboratory (Marseille, France), for valuable editorial assistance during the drafting of this manuscript.

\section{References}

[1] Khoddami, A., Wilkes, M.A. and Roberts, T.H. (2013) Techniques for Analysis of Plant Phenolic Compounds. Molecules, 18, 2328-2375. http://dx.doi.org/10.3390/molecules18022328

[2] Tsao, R. (2010) Chemistry and Biochemistry of Dietary Polyphenols. Nutrients, 2, 1231-1246. http://dx.doi.org/10.3390/nu2121231

[3] Ferrazzano, G.F., Amato, I., Ingenito, A., Zarrelli, A., Pinto, G. and Pollio, A. (2011) Plant Polyphenols and Their Anti-Cariogenic Properties: A Review. Molecules, 16, 1486-1507. http://dx.doi.org/10.3390/molecules16021486

[4] Berghe, W.V. (2012) Epigenetic Impact of Dietary Polyphenols in Cancer Chemoprevention: Lifelong Remodeling of Our Epigenomes. Pharmacological Research, 65, 565-576. http://dx.doi.org/10.1016/j.phrs.2012.03.007

[5] Kazeem, M.I., Akanji, M.A., Hafizur, R.M. and Choudhary, M.I. (2012) Antiglycation, Antioxidant and Toxicological Potential of Polyphenol Extracts of Alligator Pepper, Ginger and Nutmeg from Nigeria. Asian Pacific Journal of Tropical Biomedicine, 2, 727-732. http://dx.doi.org/10.1016/S2221-1691(12)60218-4

[6] Konaté, K., Hilou, A., Mavoungou, J.F., Lepengué, A.N., Souza, A., Barro, N., Datté, J.Y., M’Batchi, B. and Nacoulma, O.G. (2012) Antimicrobial Activity of Polyphenol-Rich Fractions from Sida alba L. (Malvaceae) against Cotrimoxazol-Resistant Bacteria Strains. Annals of Clinical Microbiology and Antimicrobials, 11, 1-6. http://dx.doi.org/10.1186/1476-0711-11-5

[7] Lolayekar, N. and Shanbhag, C. (2012) Polyphenols and Oral Health. RSBO, 9, 74-84.

[8] Dragovic-Uzelac, V., Levaj, B., Mrkic, V., Bursac, D. and Boras, M. (2007) The Content of Polyphenols and Carotenoids in Three Apricot Cultivars Depending on Stage of Maturity and Geographical Region. Food Chemistry, 102, 966-975. http://dx.doi.org/10.1016/j.foodchem.2006.04.001

[9] Ignat, I., Volf, I. and Popa, V.I. (2011) A Critical Review of Methods for Characterisation of Polyphenolic Compounds in Fruits and Vegetables. Food Chemistry, 126, 1821-1835. http://dx.doi.org/10.1016/j.foodchem.2010.12.026

[10] D’Archivio, M., Filesi, C., Di Benedetto, R., Gargiulo, R., Giovannini, C. and Masella, R. (2007) Polyphenols, Dietary Sources and Bioavailability. Annali dell'Istituto Superiore di Sanità, 43, 348-361.

[11] N’Guessan, A.H.O., Déliko, C.E.D., Mamyrbékova-Békro, J.A. and Békro, Y.A. (2011) Teneurs en composés phénoliques de 10 plantes médicinales employées dans la tradithérapie de l’hypertension artérielle, une pathologie émergente en Côte d'Ivoire. Revue de Génie Industriel, 6, 55-61.

[12] Okuda, T. and Ito, H. (2011) Tannins of Constant Structure in Medicinal and Food Plants-Hydrolyzable Tannins and Polyphenols Related to Tannins. Molecules, 16, 2191-2217. http://dx.doi.org/10.3390/molecules16032191

[13] Cosmulescu, S. and Trandafir, I. (2011) Seasonal Variation of Total Phenols in Leaves of Walnut (Juglans regia L.). Journal of Medicinal Plants Research, 5, 4938-4942.

[14] Generalic, I., Skroza, D., Surjaka, J., Mozinab, S.S., Ljubenkovc, I., Katalinic, A., Simate, V. and Katalinic, V. (2012) Seasonal Variations of Phenolic Compounds and Biological Properties in Sage (Salvia officinalis L.). Chemistry \& Biodiversity, 9, 441-456. http://dx.doi.org/10.1002/cbdv.201100219

[15] Raal, A., Orav, A., Pussa, T., Valner, C., Malmiste, B. and Arak, E. (2012) Content of Essential Oil, Terpenoids and Polyphenols in Commercial Chamomile (Chamomilla recutita L. Rauschert) Teas from Different Countries. Food Chemistry, 131, 632-638. http://dx.doi.org/10.1016/j.foodchem.2011.09.042

[16] Ghasemi, K., Ghasemi, Y., Ehteshamnia, A., Nabavi, S.M., Nabavi, S.F., Ebrahimzadeh, M.A. and Pourmorad, F. (2011) Influence of Environmental Factors on Antioxidant Activity, Phenol and Flavonoids Contents of Walnut (Juglans regia L.) Green husks. Journal of Medicinal Plants Research, 5, 1128-1133.

[17] Bruni, R. and Sacchetti, G. (2009) Factors Affecting Polyphenol Biosynthesis in Wild and Field Grown St. John's Wort (Hypericum perforatum L. Hypericaceae/Guttiferae). Molecules, 14, 682-725. http://dx.doi.org/10.3390/molecules14020682

[18] Trabelsi, N., Megdiche, W., Ksouri, R., Falleh, H., Oueslati, S., Soumaya, B., Hajlaoui, H. and Abdelly, C. (2010) Solvent Effects on Phenolic Contents and Biological Activities of the Halophyte Limoniastrum monopetalum Leaves. LWT-Food Science and Technology, 43, 632-639.

[19] Gironi, F. and Piemonte, V. (2011) Temperature and Solvent Effects on Polyphenol Extraction Process from Chestnut Tree Wood. Chemical Engineering Research and Design, 89, 857-862. http://dx.doi.org/10.1016/j.cherd.2010.11.003

[20] Falleh, H., Ksouri, R., Lucchessi, M.E., Abdelly, C. and Magné, C. (2012) Ultrasound-Assisted Extraction: Effect of Extraction Time and Solvent Power on the Levels of Polyphenols and Antioxidant Activity of Mesembryanthemum edule L. Aizoaceae Shoots. Tropical Journal of Pharmaceutical Research, 11, 243-249. 
http://dx.doi.org/10.4314/tjpr.v11i2.10

[21] Tan, P.W., Tan, C.P. and Ho, C.W. (2011) Antioxidant Properties: Effects of Solid-to-Solvent Ratio on Antioxidant Compounds and Capacities of Pegaga (Centella asiatica). International Food Research Journal, 18, 557-562.

[22] Santana, C.M., Ferrera, Z.S., Padrón, M.E.T. and Rodríguez, J.J.S. (2009) Methodologies for the Extraction of Phenolic Compounds from Environmental Samples: New Approaches. Molecules, 14, 298-320. http://dx.doi.org/10.3390/molecules14010298

[23] Stalikas, C.D. (2010) Phenolic Acids and Flavonoids: Occurrence and Analytical Methods. Methods in Molecular Biology, 610, 65-90. http://dx.doi.org/10.1007/978-1-60327-029-8_5

[24] Jace, D.E. and Shahidul, I. (2012) Effects of Extraction Procedures, Genotypes and Screening Methods to Measure the Antioxidant Potential and Phenolic Content of Orange-Fleshed Sweetpotatoes (Ipomoea batatas L.). American Journal of Food Technology, 7, 50-61. http://dx.doi.org/10.3923/ajft.2012.50.61

[25] Garcia-Salas, P., Morales-Soto, A., Segura-Carretero, A. and Fernández-Gutiérrez, A. (2010) Phenolic-Compound-Extraction Systems for Fruit and Vegetable Samples. Molecules, 15, 8813-8826. http://dx.doi.org/10.3390/molecules15128813

[26] Chirinos, R., Rogez, H., Campos, D., Pedreschi, R. and Larondelle, Y. (2007) Optimisation of Extraction Conditions of Antioxidant Phenolic Compounds from Mashua (Tropaeolum tuberosum Ruíz \& Pavón) Tubers. Journal of Separation and Purification Technology, 55, 217-225. http://dx.doi.org/10.1016/j.seppur.2006.12.005

[27] Kanyonga, P.M., Faouzi, M.A., Meddah, B., Mpona, M., Essassi, E.M. and Cherrah, Y. (2011) Assessment of Methanolic Extract of Marrubium vulgare for Antiinflammatory, Analgesic and Anti-Microbiologic Activities. Journal of Chemical and Pharmaceutical Research, 3, 199-204.

[28] Belhattab, R. and Larous, L. (2006) Essential oil Composition and Glandular Trichomes of Marrubium vulgare L. Growing Wild in Algeria. Journal of Essential Oil Research, 18, 369-373. http://dx.doi.org/10.1080/10412905.2006.9699116

[29] El Bardai, S., Morel, N., Wibo, M., Fabre, N., Liabres, G., Lyoussi, B. and Quetin-Leclercq, J. (2003) The Vasorelaxant Activity of Marrubenol and Marrubiin from Marrubium vulgare. Planta Medica, 69, 75-77. http://dx.doi.org/10.1055/s-2003-37042

[30] Sahpaz, S., Garbacki, N., Tits, M. and Bailleul, F. (2012) Isolation and Pharmacological Activity of Phenylpropanoid Esters from Marrubium vulgare. Journal of Ethnopharmacology, 79, 389-392. http://dx.doi.org/10.1016/S0378-8741(01)00415-9

[31] Kurbatova, N.V., Muzychkina R.A., Mukhitdinov, N.M. and Parshina, G.N. (2013) Comparative Phytochemical Investigation of the Composition and Content of Biologically Active Substances in Marrubium vulgare and Marrubium alternidens. Chemistry of Natural Compounds, 39, 501-502. http://dx.doi.org/10.1023/B:CONC.0000011128.64886.f4

[32] Nawwar Mahmoud, A.M., El-Mousallamy, A.M.D., Barakat, H.H., Buddrus, J. and Linscheid, M. (1989) Flavonoid Lactates from Leaves of Marrubium vulgare. Phytochemistry, 28, 3201-3206. http://dx.doi.org/10.1016/0031-9422(89)80307-3

[33] Vergara-Galicia, J., Aguirre-Crespo, F., Tun-Suarez, A., Crespo, A.A., Estrada-Carrillo, M., Jaimes-Huerta, I., FloresFlores, A., Estrada-Soto, S. and Ortiz-Andrade, R. (2012) Acute Hypoglycemic Effect of Ethanolic Extracts from Marrubium vulgare. Phytopharmacology, 3, 54-60.

[34] Meyre-Silva, C., Yunes, R.A., Schlemper, V., Campos-Buzzi, F. and Cechinel-Filho, V. (2005) Analgesic Potential of Marrubiin Derivatives, a Bioactive Diterpene Present in Marrubium vulgare L. (Lamiaceae). Il Farmaco, 60, 312-326. http://dx.doi.org/10.1016/j.farmac.2005.01.003

[35] Boudjelal, A., Henchiri, C., Siracusa, L., Sari, M. and Ruberto, G. (2012) Compositional Analysis and in Vivo AntiDiabetic Activity of Wild Algerian Marrubium vulgare L. Infusion. Fitoteparia, 2, 286-292.

[36] De Jesus, R.A. and Cechinel Filho, V. (2000) Analysis of the Antinociceptive Properties of Marrubiin Isolated from Marrubium vulgare L. Phytomedicine, 7, 111-115. http://dx.doi.org/10.1016/S0944-7113(00)80082-3

[37] Pukalskas, A., Rimantas Venskutonis, P., Salido, S., De Waard, P. and Van Beek., T.A. (2012) Isolation, Identification and Activity of Natural Antioxidants from Horehound (Marrubium vulgare L.) Cultivated in Lithuania. Food Chemistry, 130, 695-701. http://dx.doi.org/10.1016/j.foodchem.2011.07.112

[38] Li, H., Wong, C., Cheng, K. and Chen, F. (2008) Antioxidant Properties in Vitro and Total Phenolic Contents in Methanol Extracts from Medicinal Plants. Lebensmittel-Wissenschaft und -Technologie, 41, 385-390.

[39] Chew, K.K., Ng, S.Y., Thoo, Y.Y., Khoo, M.Z., Wan Aida, W.M. and Ho, C.W. (2011) Effect of Ethanol Concentration, Extraction Time and Extraction Temperature on the Recovery of Phenolic Compounds and Antioxidant Capacity of Centella asiatica Extracts. International Food Research Journal, 18, 571-578.

[40] Ceto, X., Gutiérrez, J.M., Gutiérrez, M., Céspedes, F., Capdevila, J., Manguez, S., Jiménez-Jorquera, C. and Del Valle, 
M. (2012) Determination of Total Polyphenol Index in Wines Employing a Voltammetric Electronic Tongue. Analytica Chimica Acta, 732, 172-179. http://dx.doi.org/10.1016/j.aca.2012.02.026

[41] Liao, L., Yin, X. and Wang, Z. (2012) Optimization of Total Flavonoid Extraction in Callicarpa nudiflora Hook. et Arn. Using Response Surface Methodology. Journal of Medicinal Plants Research, 6, 5038-5047.

[42] Zheng, N., Wang, Z., Shi, Y. and Lin, J. (2012) Evaluation of the Antifungal Activity of Total Flavonoids Extract from Patrinia Villosa Juss and Optimization by Response Surface Methodology. African Journal of Microbiology Research, 6, 586-593. http://dx.doi.org/10.5897/AJMR11.1393

[43] Naczk, M. and Shahidi, F. (2004) Extraction and Analysis of Phenolics in Food. Journal of Chromatography, 1054, 95-111. http://dx.doi.org/10.1016/j.chroma.2004.08.059

[44] Jakopic, J., Veberic, R. and Stampar, F. (2009) Extraction of Phenolic Compounds from Green Walnut Fruits in Different Solvents. Acta Agriculturae Slovenica, 93, 11-15. http://dx.doi.org/10.2478/v10014-009-0002-4

[45] Ghasemzadeh, A., Jaafar, H.Z.E. and Rahmat, A. (2011) Effects of Solvent Type on Phenolics and Flavonoids Content and Antioxidant Activities in Two Varieties of Young Ginger (Zingiber officinale Roscoe) Extracts. Journal of Medicinal Plants Research, 5, 1147-1154.

[46] Mohammedi, Z. and Atik, F. (2011) Impact of Solvent Extraction Type on Total Polyphenols Content and Biological Activity from Tamarix aphylla (L.) Karst. International Journal of Pharma and Bio Sciences, 2, 609-615.

[47] Iqbal, S., Younas, U., Chan, K.W., Zia-Ul-Haq, M. and Ismail, M. (2012) Chemical Composition of Artemisia annua L. Leaves and Antioxidant Potential of Extracts as a Function of Extraction Solvents. Molecules, 17, 6020-6032. http://dx.doi.org/10.3390/molecules17056020

[48] Lapornik, B., Prosek, M. and Wondra, A.G. (2005) Comparison of Extracts Prepared from Plant By-Products Using Different Solvents and Extraction Time. Journal of Food Engineering, 71, 214-222. http://dx.doi.org/10.1016/j.jfoodeng.2004.10.036

[49] Turkmen, N., Sari, F. and Velioglu, S. (2006) Effect of Extraction Solvents on Concentration and Antioxidant Activity of Black and Black Mate Polyphenols Determined by Ferrous Tartrate and Folin-Ciocalteu Methods. Food Chemistry, 99, 838-841. http://dx.doi.org/10.1016/j.foodchem.2005.08.034

[50] Kong, K.W., Khoo, H.E., Prasad, N.K., Chew, L.Y. and Amin, I. (2013) Total Phenolics and Antioxidant Activities of Pouteria campechiana Fruit Parts. Sains Malaysiana, 42, 123-127.

[51] Sultana, B., Anwar, F. and Ashraf, M. (2009) Effect of Extraction Solvent/Technique on the Antioxidant Activity of Selected Medicinal Plant Extracts. Molecules, 14, 2167-2180. http://dx.doi.org/10.3390/molecules14062167

[52] Ben Mohamed Maoulainine, L., Jelassi, A., Hassen, I. and Ould Mohamed Salem Ould Boukhari, A. (2012) Antioxidant Proprieties of Methanolic and Ethanolic Extracts of Euphorbia helioscopia (L.) Aerial Parts. International Food Research Journal, 19, 1125-1130.

[53] Pérez, M.B., Calderón, N.L. and Croci, C.A. (2007) Radiation-Induced Enhancement of Antioxidant Activity in Extracts of Rosemary (Rosmarinus officinalis L.). Food Chemistry, 104, 585-592. http://dx.doi.org/10.1016/j.foodchem.2006.12.009

[54] Karimi, E., Oskoueian, E., Hendra, R. and Jaafar, H.Z.E. (2010) Evaluation of Crocus sativus L. Stigma Phenolic and Flavonoid Compounds and Its Antioxidant Activity. Molecules, 15, 6244-6256. http://dx.doi.org/10.3390/molecules15096244

[55] Settharaksa, S., Jongjareonrak, A., Hmadhlu, P., Chansuwan, W. and Siripongvutikorn, S. (2012) Flavonoid, Phenolic Contents and Antioxidant Properties of Thai Hot Curry Paste Extract and Its Ingredients as Affected of pH, Solvent Types and High Temperature. International Food Research Journal, 19, 1581-1587

[56] Spigno, G., Tramelli, L. and De Faveri, D.M. (2007) Effects of Extraction Time, Temperature and Solvent on Concentration and Antioxidant Activity of Grape Marc Phenolics. Journal of Food Engineering, 81, 200-208.

[57] Wina, E., Susana, I.W.R. and Tangendjaja, B. (2010) Biological Activity of Tannins from Acacia mangium Bark Extracted by Different Solvents. Media Peternakan, 33, 103-107. http://dx.doi.org/10.5398/medpet.2010.33.2.103

[58] Mazandarani, M., Zarghami Moghaddam, P., Zolfaghari, M.R., Ghaemi, E.A. and Bayat, H. (2012) Effects of Solvent Type on Phenolics and Flavonoids Content and Antioxidant Activities in Onosma dichroanthum Boiss. Journal of Medicinal Plants Research, 6, 4481-4488. http://dx.doi.org/10.5897/JMPR11.1460

[59] Antwi-Boasiako, C. and Animapauh, S.O. (2012) Tannin Extraction from the Barks of Three Tropical Hardwoods for the Production of Adhesives. Journal of Applied Sciences Research, 8(6), 2959-2965.

[60] Uma, D.B., Ho, C.W. and Aida, W.M.W. (2010) Optimization of Extraction Parameters of Total Phenolic Compounds from Henna (Lawsonia inermis) Leaves. Sains Malaysiana, 39, 119-128.

[61] Chan, S.W., Lee, C.Y., Yap, C.F., Wan Aida, W.M. and Ho, C.W. (2009) Optimisation of Extraction Conditions for Phenolic Compounds from Limau Purut (Citrus hystrix) Peels. International Food Research Journal, 16, 203-213. 
[62] Yilmaz, Y. and Toledo, R.T. (2005) Oxygen Radical Absorbance Capacities of Grape/Wine Industry Byproducts and Effect of Solvent Type on Extraction of Grape Seed Polyphenols. Journal of Food Composition and Analysis, 19, 4148. http://dx.doi.org/10.1016/j.jfca.2004.10.009

[63] Butnariu, M. and Coradini, C.Z. (2012) Evaluation of Biologically Active Compounds from Calendula officinalis Flowers Using Spectrophotometry. Chemistry Central Journal, 6, 35-42. http://dx.doi.org/10.1186/1752-153X-6-35

[64] Fernandes, A.J.D., Ferreira, M.R.A., Randau, K.P., De Souza, T.P. and Soares, L.A.L. (2012) Total Flavonoids Content in the Raw Material and Aqueous Extractives from Bauhinia monandra Kurz (Caesalpiniaceae). The Scientific World Journal, 2012, Article ID: 923462.

[65] Musa, K.H., Abdullah, A., Jusoh, K. and Subramaniam, V. (2011) Antioxidant Activity of Pink-Flesh Guava (Psidium guajava L.): Effect of Extraction Techniques and Solvents. Food Analytical Methods, 4, 100-107. http://dx.doi.org/10.1007/s12161-010-9139-3

[66] Downey, M.O. and Hanlin, R.L. (2010) Comparison of Ethanol and Acetone Mixtures for Extraction of Condensed Tannin from Grape Skin. South African Journal of Enology and Viticulture, 31, 154-159.

[67] Medini, F., Ksouri, R., Falleh, H., Megdiche, W., Trabelsi, N. and Abdelly, C. (2011) Effects of Physiological Stage and Solvent on Polyphenol Composition, Antioxidant and Antimicrobial Activities of Limonium densiflorum. Journal of Medicinal Plants Research, 5, 6719-6730.

[68] Shad, M.A., Nawaz, H., Rehman, T., Ahmad, H.B. and Hussain, M. (2012) Optimization of Extraction Efficiency of Tannins from Cichorium intybus L.: Application of Response Surface Methodology. Journal of Medicinal Plants Research, 6, 4467-4474.

[69] Zhao, S., Liu, J.Y., Chen, S.Y., Shi, L.L., Liu, Y.J. and Ma, C. (2011) Antioxidant Potential of Polyphenols and Tannins from Burs of Castanea mollissima Blume. Molecules, 16, 8590-8600. http://dx.doi.org/10.3390/molecules16108590

[70] Hismath, I., Wan Aida, W.M. and Ho, C.W. (2011) Optimization of Extraction Conditions for Phenolic Compounds from Neem (Azadirachta indica) Leaves. International Food Research Journal, 18, 931-939.

[71] Franco, D., Sineiro, J., Rubilar, M., Sanchez, M., Jerez, M., Pinelo, M., Costoya, N. and José Nunez, M. (2008) Polyphenols from Plant Materials: Extraction and Antioxidant Power. Electronic Journal of Environmental, Agricultural and Food Chemistry, 7, 3210-3216.

[72] Sardsaengjun, C. and Jutiviboonsuk, A. (2010) Effect of Temperature and Duration Time on Polyphenols Extract of Areca catechu Linn. Seeds. Thai Pharmaceutical and Health Science Journal, 5, 14-17.

[73] Dent, M., Dragovi-Uzelac, V., Peni, M., Brncic, M., Bosiljkov, T. and Levaj, B. (2013) The Effect of Extraction Solvents, Temperature and Time on the Composition and Mass Fraction of Polyphenols in Dalmatian Wild Sage (Salvia officinalis L.) Extracts. Food Technology and Biotechnology, 51, 84-91.

[74] Naczk, M. and Shahidi, F. (2006) Phenolics in Cereals, Fruits and Vegetables: Occurrence, Extraction and Analysis. Journal of Pharmaceutical and Biomedical Analysis, 41, 1523-1542. http://dx.doi.org/10.1016/j.jpba.2006.04.002

[75] Garcia-Marquez, E., Roman-Guerrero, A., Perez-Alonso, C. and Cruz-Sosa, F. (2012) Effect of Solvent-Temperature Extraction Conditions on the Initial Antioxidant Activity and Total Phenolic Content of Muitle Extracts and Their Decay upon Storage at Different pH. Revista Mexicana de Ingeniería Química, 11, 1-10.

[76] Zhekova, G. and Pavlov, D. (2012) Influence of Different Factors on Tannins and Flavonoids Extraction of Some Thyme Varieties Representatives of Thymol, Geraniol and Citral Chemotype. Agricultural Science and Technology, 4, 148-153.

[77] Liu, W., Yu, Y., Yang, R., Wan, C., Xu, B. and Cao, S. (2010) Optimization of Total Flavonoid Compound Extraction from Gynura medica Leaf Using Response Surface Methodology and Chemical Composition Analysis. International Journal of Molecular Sciences, 11, 4750-4763. http://dx.doi.org/10.3390/ijms11114750

[78] Moosophin, K., Wetthaisong, T., Seeratchakot, L. and Kokluecha, W. (2010) Tannin Extraction from Mangosteen Peel for Protein Precipitation in Wine. KKU Research Journal, 15, 377-385.

[79] Mustapha, M.B., Adefisan, H.A. and Olawale, A.S. (2012) Studies of Tannin Extract Yield from Parkia clappertoniana's Husk. Journal of Applied Sciences Research, 8, 65-68.

[80] Zam, W., Bashour, G., Abdelwahed, W. and Khayata, W. (2012) Effective Extraction of Polyphenols and Proanthocyanidins from Pomegranate's Peel. International Journal of Pharmacy and Pharmaceutical Sciences, 4, 675-682.

[81] Druzynska, B., Stepniewska, A. and Wolosiak, R. (2007) The Influence of Time and Type of Solvent on Efficiency of the Extraction of Polyphenols from Green Tea and Antioxidant Properties Obtained Extracts. Acta Scientiarum Polonorum. Technologia Alimentaria, 6, 27-36.

[82] Jokic, S., Velic, D., Bilic, M., Bucic-Kojic, A., Planinic, M. and Tomas, S. (2010) Modelling of the Process of SolidLiquid Extraction of Total Polyphenols from Soybeans. Czech Journal of Food Sciences, 28, 206-212. 
[83] Perva-Uzunalic, A., Skerget, M., Knez, Z., Weinreich, B., Otto, F. and Grucher, S. (2006) Extraction of Active Ingredients from Green Tea (Camellia sinensis), Extraction Efficiency of Major Catechins and Caffeine. Food Chemistry, 96, 597-605. http://dx.doi.org/10.1016/j.foodchem.2005.03.015

[84] Akowuah, G.A., Mariam A. and Chin, J. H. (2009) The Effect of Extraction Temperature on Total Phenols and Antioxidant Activity of Gynura procumbens Leaf. Pharmacognosy Magazine, 5, 81-85.

[85] Chew, K.K., Thoo, Y.Y., Khoo, M.Z., Wan Aida, W.M. and Ho, C.W. (2011) Effect of Ethanol Concentration, Extraction Time and Extraction Temperature on the Recovery of Phenolic Compounds and Antioxidant Capacity of Orthosiphon stamineus Extracts. International Food Research Journal, 18, 427-1435.

[86] Naeem, S., Ali, M. and Mahmood, A. (2012) Optimization of Extraction Conditions for the Extraction of Phenolic Compounds from Moringa oleifera Leaves. Pakistan Journal of Pharmaceutical Sciences, 25, 535-541.

[87] Davidov-Pardo, G., Arozarena, M.R.I. and Marin-Arroyo, M.R. (2011) Stability of Polyphenolic Extracts from Grape Seeds after Thermal Treatments. European Food Research and Technology, 232, 211-220. http://dx.doi.org/10.1007/s00217-010-1377-5

[88] Biesaga, M. and Pyrzynska, K. (2013) Stability of Bioactive Polyphenols from Honey during Different Extraction Methods. Food Chemistry, 136, 46-54. http://dx.doi.org/10.1016/j.foodchem.2012.07.095

[89] Juntachote, T., Berghofer, E., Bauer, F. and Siebenhandl, S. (2006) The Application of Response Surface Methodology to the Production of Phenolic Extracts of Lemon Grass, Galangal, Holy Basil and Rosemary. International Journal of Food Science and Technology, 41, 121-133. http://dx.doi.org/10.1111/j.1365-2621.2005.00987.x

[90] Al-Farsi, M.A. and Lee, C.Y. (2007) Optimization of Phenolics and Dietary Fibre Extraction from Date Seeds. Food Chemistry, 108, 977-985. http://dx.doi.org/10.1016/j.foodchem.2007.12.009

[91] Wang, J., Sun, B., Cao, Y., Tian, Y. and Li, X. (2008) Optimisation of Ultrasound-Assisted Extraction of Phenolic Compounds from Wheat Bran. Food Chemistry, 106, 804-810. http://dx.doi.org/10.1016/j.foodchem.2007.06.062 
Scientific Research Publishing (SCIRP) is one of the largest Open Access journal publishers. It is currently publishing more than 200 open access, online, peer-reviewed journals covering a wide range of academic disciplines. SCIRP serves the worldwide academic communities and contributes to the progress and application of science with its publication.

Other selected journals from SCIRP are listed as below. Submit your manuscript to us via either submit@scirp.org or Online Submission Portal.
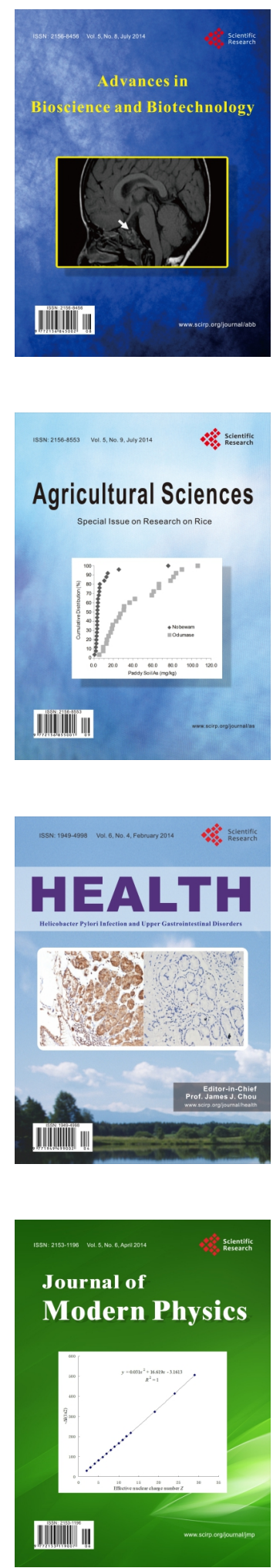
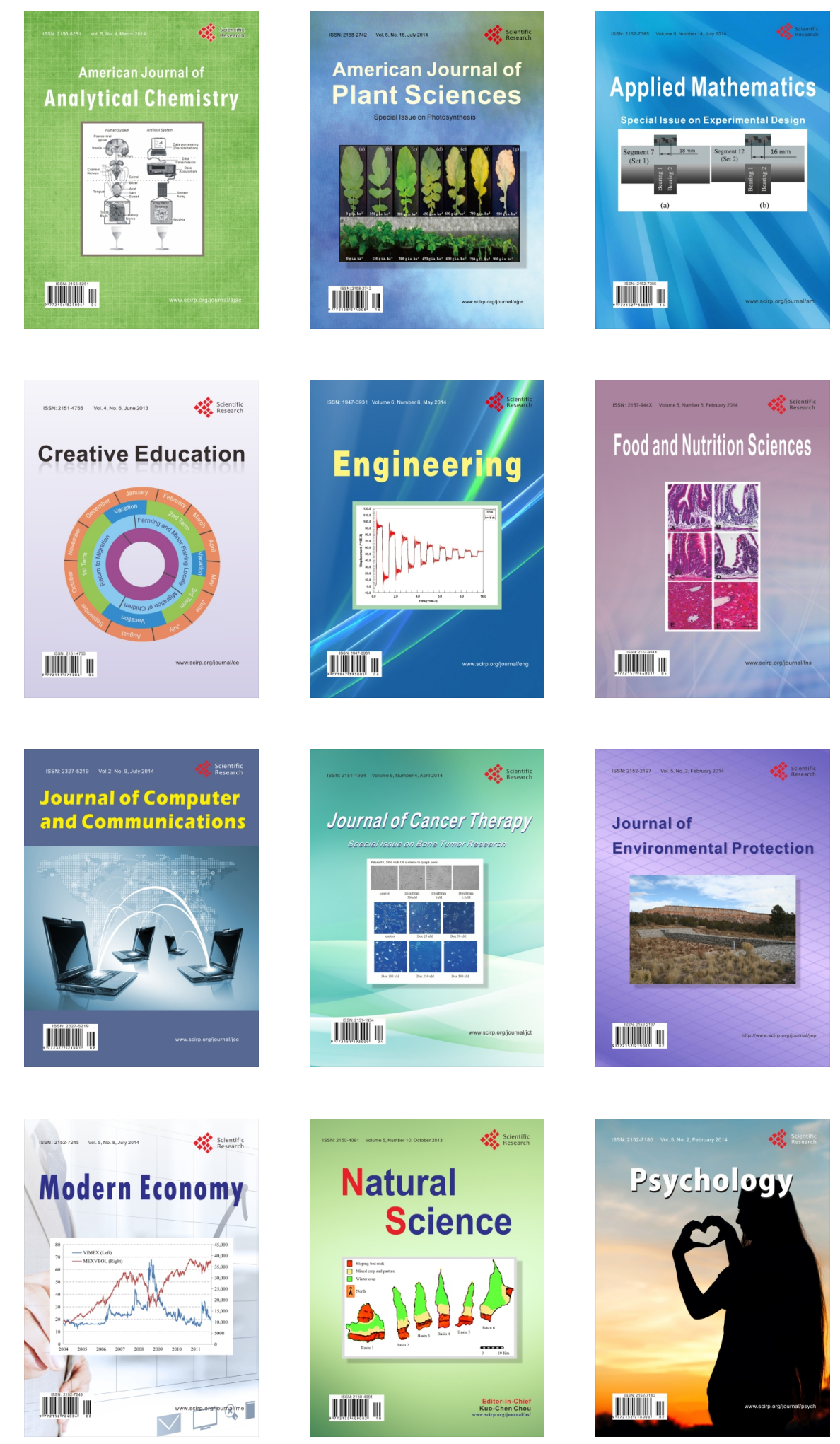